\title{
Nepal and India Relation After 12 Points Understanding
}

\author{
Associate Professor, Girdhari Dahal, PhD
}

Department of Political Science, Tribhuvan University, Prithvi

Narayan Campus, Pokhara, Nepal

\begin{abstract}
With multidimensional aspects, Nepal India relation is historical, social, political and culturally embodied. Both countries adhere to a unique relationship of friendship and cooperation characterized by open borders and deep-rooted people-to-people contacts of kinship and culture. Pedestal on secondary data this article aims to discuss the major developments in Indo-Nepal relation after 12 points understanding. Nepalese and Indian governments, in order to review the past treaties and agreements between the two countries, made EPG of four members each from both countries. Similarly, Nepal and India exchanged high level visits between them. Nepal made a new constitution in 2015 and promulgated it. However, India was not satisfied with some of the content of it, so India imposed unilateral blockade. Later, Nepal India relation was normalized, and again, Nepal and India have a dispute on Limpiyadhura-Lipulekh border. The vital concern is what has happened to the relations built on historical ties? This paper looks at the relations India once had with Nepal, and where it stands today. There have been many ups and downs in Nepal India relation after 12 points understanding and even during the present border dispute. However, all problems and disputes can be solved through diplomatic dialogues at various levels. Bilateral relations can grow further with unfaltering commitment to the doctrines of peaceable coexistence, sovereign equality,
\end{abstract}


and understanding of each other's aspirations and sensitivities.

Keywords : Bilateral relation, blockade, high level visits, promulgation.

\section{Introduction}

Nepal-India relations have a long history. Although, in this article Nepal India relation after 12-point understanding will be discussed, 12 point understanding is a turning point in the political history of Nepal. It opened the door for Constitutional Assembly (CA) and Federal Democratic Republic Nepal (Dahal, 2015). In this 12-point understanding, the political parties pledge to work towards democracy, peace, prosperity and social advancement and ending autocratic monarchy. After this understanding, the people's mass movement of 2006 was successfully held in Nepal. There after the first CA was formed, this just started the process of making the constitution. Constitution and finally the second CA promulgated the new constitution in 2015. As a sovereign nation, Nepal promulgated its constitution independently. However, India had some vested interest and it wanted its interest to be incorporated in the new constitution. As a result, India blocked its border to Nepal without any information or announcement. The Nepali people suffered from the blockade for three months. In the meantime, Nepal India relation was very tense. Being a landlocked country, Nepal has transit rights as provisioned by international laws. However, by imposing an unannounced blockade, India violated transit rights of landlocked country Nepal. It was not the first time India has imposed blockade to Nepal. In the previous time also, India had imposed similar blockade in Nepal. Being a neighbor, India has not played the role of a good neighbor. Later Indo-Nepal relation was normalized after a series of official and unofficial political visits and dialogues from both sides. On the other hand, Nepal 
and India have formed Eminent Person Group (EPG) of four members each from both countries in order to review all the treaties and agreements between the two countries (Ministry of External Affairs, 2014). EPG has already completed its assigned task; however, Indian Prime Minister Narendra Modi has not received its report yet. This report is expected to add one more brick to bring harmonious relation between Nepal India relation. Meanwhile, the latest Limpiyadhura-Lipulekh-Kalapani dispute and the consequent developments have, again, tensed the NepalIndia relation and it is unknown till the moment about how the case is settled.

\section{Objective and Methodology}

The objective of this paper is to discuss the major developments in Nepal India relation after 12 points understanding. The major concern is on what has happened to the relations built on historical ties. This study is descriptive and analytical in nature. The study is descriptive as it primarily focuses on describing the nature of Indo-Nepal relations. The paper is solely based on qualitative secondary data congregated from different secondary sources viz. library books, journals, booklets and internet sources. The qualitative data assisted in the analysis of the subject under study.

\section{High Level Visit}

Exchange of high-level visits definitely support strengthening bilateral relations between the two countries. When the People's Movement of 2006 was successful, thereafter Nepalese and Indian leaders had regular dialogues as well as both countries frequently exchanged high level visits. Nepalese President, Prime Minister, Foreign Minister and other ministers visited India on different occasions that helped to keep friendly relation with India. Similarly, Indian President, Prime Minister, Foreign 
Minister and other Ministers visited Nepal.

Dr. Ram Baran Yadav, the first President of Nepal, paid a state visit to India in February 2010 on the invitation of Indian President Ms. Pratibha Devisingh Patil. This high-level visit supported in deepening the Nepal India relation (Ministry of Foreign Affairs Nepal, 2019). Nepalese President Dr. Ram Baran Yadav, again, visited India on December 24-29, 2012. Likewise, President of Nepal, Mrs. Bidhya Devi Bhandari paid a state visit to India on 17-21 April 2017 (Ministry of Foreign Affairs Nepal, 2019). On the other hand, President of India Shree Pranab Mukherjee paid a state visit to Nepal on 02-04 November 2016. This was the first state visit by an Indian President to Nepal after a gap of 18 years (Embassy of India in Kathmandu, 2019). Thus, presidential level visits by both sides helped to strengthen Nepal-India relation.

There were prime ministerial level visits as well between Nepal and India. The then Prime Minister of Nepal, Mr. Sushil Koirala, visited India to attend the swearing- in ceremony of elected Prime Minister of India, Mr Narendra Modi, on May 2014. Similarly, Nepalese Prime Minister Mr. K.P. Sharma Oli paid a state visit to India on 19-24 February, 2016. Prime Minister Mr. K.P. Sharma Oli, again, paid a state visit to India on 06-08 April 2018 (Ministry of Foreign Affairs Nepal, 2019). Nepalese Prime Minister Mr. Pushpa Kamal Dahal 'Prachanda' visited India twice, a state visit on 15-18 September, 2016 and on 1517 October, 2016 to participate in the 1st BRICS-BIMSTEC leaders' summit in Goa. Prime Minister of Nepal Mr. K.P. Sharma Oli visited India, for the third time, from 30-31 May 2019 to attend the swearing-in ceremony of Prime Minister, Shri Narendra Modi (Ministry of Foreign Affairs Nepal, 2019).

Indian Prime Minister Shri Narendra Modi visited Nepal twice in 2014 - on 03-04 August for a bilateral visit and on 25-27 
November for the 18th SAARC Summit. Similarly, Prime Minister Narendra Modi started his two-day visit to Nepal from Janakpur, the heartland of Madhesh, on May 11 to 12, 2018 (The Hindustan Times, 2018). Before Prime Minister Narendra Modi, the last Indian Prime Minister who had visited Nepal was IK Gujral in June, 1997.

Pradeep Kumar Gyawali, Minister for Foreign Affairs, visited New Delhi on 10 January 2019 to attend the fourth edition of the Raisina Dialogue (Embassy of India in Kathmandu, 2019). The then Deputy Prime Minister and Minister for Foreign Affairs Mr. Krishna Bahadur Mahara visited India in July 2017 on the invitation of Sushma Swaraj, Minister of External Affairs of India. Then Minister of Foreign Affairs Dr. Prakash Sharan Mahat visited India in October 2016 leading a Nepali delegation to participate in the 4th meeting of Nepal-India Joint Commission. Then Minister for Foreign Affairs Dr. Prakash Sharan Mahat visited India in September 2016. The then Deputy Prime Minister and Minister for Foreign Affairs Mr. Kamal Thapa visited India in November 2015.

\section{New Constitution Making Process}

Prior to the constitution making process, Nepal India relation was good. Indian Prime Minister Narendra Modi visited Nepal in August 2014. Modi addressed the Parliament of Nepal. He advised the members of CA to concentrate on the constitution making process (with Rishi Man) (Ministry of External Affairs, 2014). He stressed that the constitution should address the interest of people residing in Himalaya, Hill and Terai as well as to fulfill the dream of people of all religions, languages, cultures and castes. He further added, in his speech, that India would not interfere in the constitution making process of Nepal as Nepal is the sovereign nation (Ministry of External Affairs, 2014). He 
further said that Nepal is the land of Pashupatinath, Muktinath, Risimuni, Tapovumi and birthplace of Buddha. On his visit, the government of Nepal and government of India issued a 35 Point joint statement. But unfortunately, next year, after the promulgation of new constitution, India imposed a blockade to Nepal without making any announcement as it was dissatisfied with some of the contents of the constitution.

Modi government had some suggestions to be included in the new constitution of Nepal. India wanted Nepal to follow its suggestion. It was not acceptable for Nepal. Nepal did not follow the Indian suggestion as Nepal is a sovereign and independent nation. No other nation has any right to provide suggestions and feedback for the new constitution going to be made by CA. CA is the symbol of the sovereign power as it was made by the sovereign people of Nepal (Dahal, 2015). So, the leader of political parties independently decided to announce the constitution of Nepal in 2015. Two days before the promulgation of the Constitution of Nepal, Indian Prime Minister Modi had sent a diplomat to Nepal as a special envoy for the same purpose but Nepal did not follow it.

Then, in September 2015, just two days before the sovereign Constituent Assembly (CA) was to promulgate the new constitution, Indian Foreign Secretary S. Jayshankar visited Nepal as a special envoy of the Indian PM to coerce Nepalese leaders to postpone the promulgation of the constitution. Nepalese leaders defied it as they were not in a position to postpone the schedule endorsed by the CA. (Tiwari, 2015).

Nepal's Second Constituent Assembly promulgated a Constitution on 20 September 2015 amid protests by Madhesbased parties and other groups. The Government of India has expressed grave concern regarding the ongoing protests and 
has urged the Government of Nepal to make efforts to resolve all issues through a credible political dialogue (Embassy of India Kathmandu, 2015). After the promulgation of the new constitution of Nepal in September 2015, China and other friendly countries of the world welcomed it. But India did not welcome it. India merely noted the promulgation of the new constitution of Nepal. Similarly, Indian Prime Minister Modi tried to collect international support and On a visit to the United Kingdom in a joint statement he spoke on Nepal's constitution. But he did not get the support as expected. Then India decided to impose a trade embargo to Nepal in order to put pressure on Nepal. India supported the demand of Madhesh based political parties. Madesh based parties wanted 'One Madesh One Pradesh' and also demanded that 100 seats out of 165 seats be allotted for the Madesh Pradesh.

Consequently, the major Madhesh-based parties did not sign constitution which had serious flaws. Provision was made for a 165 -member parliament in the new constitution. But the constituencies were developed in a way that the people of hill and mountain regions get 100 seats, though their share in Nepal's total population is less than 50 per cent. On the other hand, the Terai region inhabits over half of the country's population, but it has been allocated only 65 seats. (Jha, 2015)

India wanted a dominating role in Nepal's affairs. Madhesh Movement of Nepal is a political movement launched by various political parties, especially those based in Madhesh, for equal rights, dignity and identity of Madhesi and Tharu. The Madhes movement mainly demanded two autonomous states in the Terai - one from Jhapa to Parasi, the other from Chitwan to Kanchanpur. So the Indian government supported the Madhesh 
movement and imposed a blockade on Nepal without any official announcement. India never accepted that it imposed a blockade on Nepal but the fact easily proves it.

Indian Prime Minister played a dual role in the constitution making process of Nepal (Dahal, 2019). On the one hand, while addressing CA members in the parliament, he asked CA members to concentrate with 'Rishi Man' in the constitution making process. On the other hand, after the constitution was finally promulgated, instead of welcoming it, he unofficially imposed a blockade on Nepal as a gesture of dissatisfaction to Nepal's new constitution.

\section{Blockade in Nepal}

Nepal had announced the new CA made constitution of Nepal in 2015 (Dahal, 2015). Two days before the announcement of the new constitution, Indian Prime Minister sent his special envoy to convince Nepal to delay the constitution promulgation date for some more days and also asked Nepal to address the demand of the Madhes-based political parties through the dialogue. Nepal is the sovereign nation and it announced the new constitution. The CA represents the sovereign power of the people. Facts show that nowhere in the world hundred percent CA members have supported the new constitution. For example, new constitution of India was promulgated in 1950 with hardly two third majority support of its CA members and the constitution of the USA was approved by two third states only after two years of its announcement. Constitution of the USA was made in 1787 but it was implemented in 1789 after two third states finally approved it. In Nepal, almost 90 percent CA members signed in the Constitution of Nepal, 2015 (Dahal, 2015). Madhesh based political parties demanded formation of two autonomous states in the Terai: one from Jhapa to Parasi to be called Mithila state 
with Janakpur its capital and next from Chitwan to Kanchanpur to be called Buddha state with Lumbini its capital and provision of 83 parliamentary seats in Terai. Similarly, reservation of seats for the Madheshi and Tharu in administrative, security, judiciary and diplomatic service on the basis of the population (Jha, 2015).

\section{Eminent Person Group (EPG)}

Being the closest neighboring countries of South Asia, Nepal and India have historical, cultural, ethnical and socially deep-rooted relations. In history there were different modes and situations between the bilateral relation of the two countries. Nepal and India made various agreements and treaties. India is a bigger and more powerful nation than Nepal. Also, the area of India is much larger than that of Nepal, population of India is far more bigger than that of Nepal. Even India is politically stronger than Nepal. But being two sovereign and independent nations, they have equal status in the world. However, India wants to dominate and control Nepal. It wants to be like a big brother. This is not acceptable for Nepal nor for any other independent nation of the world. Both countries have to abide by the international rules and regulations.

The two Prime Ministers agreed to review, adjust and update the Treaty of Peace and Friendship of 1950 and other bilateral agreements. They welcomed the decision of the Joint Commission to direct the Foreign Secretaries of the two countries to meet and discuss a specific proposal to revise the Treaty of Peace and Friendship of 1950, which the Government of Nepal agreed to provide at the earliest. Both sides agreed that the revised Treaty should better reflect the current realities and aim to further consolidate and expand the multifaceted and deep-rooted relationships in a forwardlooking manner. (Embassy of India in Kathmandu, 2014) 
Both Nepal and India are the members of UNO, members of non-alignment movement, and founder members of SAARC. They have equal right to vote in the UNO. Thus, Nepal and India are similar and sovereign nations of the world. In the past, Nepal signed several unfair treaties with India. Now Nepal wants to review them all. It demands a fair deal between the two nations. All the discriminatory treaties and agreements are no more acceptable for Nepal. So, both countries agreed to form an EPG for the review and recommendation about the past agreements and treaties between Nepal and India. In 2014, both the Government of Nepal and the Government of India made EPG. There are eight members, four members each from Nepal and India.

\section{Results and Discussion}

The 12 points understanding between the then seven parliamentarian parties and CPN (UML) took place in Delhi, the capital city of India. This 12 points understanding paved a way for people's movement, abolishment of monarchy, establishment of federal republic nation and a new constitution for Nepal. So, this 12 points understanding is a major political event in the political history of Nepal. As this understanding took place in India, India might have expected more influence in Nepal's political affairs. But such expectation is not good for a modern democratic sovereign nation. That's why Nepal India relation is more tumultuous after the 12-points understanding. Undoubtedly 12 points understanding is a major turning point in the political history of Nepal. After that Nepal entered into new life by becoming a federal democratic republic nation. It got a new recognition of a republic country. In this period, Nepal India relations experienced more ups and downs. Nepal India relation was rejoicing when the Indian Prime Minister Narendra 
Modi addressed the CA (then Parliament) of Nepal and told CA members to concentrate on constitution making process with 'Rishi Man'. His address to the parliament was admired by the Nepalese people.

Table 1: High Level Visits

\begin{tabular}{|c|c|c|c|c|c|}
\hline $\mathrm{SN}$ & Positions & $\begin{array}{l}\text { Name of the } \\
\text { Delegate }\end{array}$ & Nation & Date & Remarks \\
\hline 1 & President & $\begin{array}{l}\text { Dr Ram Baran } \\
\text { Yadav }\end{array}$ & Nepal & Feb. 2010 & \\
\hline 2 & & $\begin{array}{l}\text { Dr Ram Baran } \\
\text { Yadav }\end{array}$ & Nepal & $\begin{array}{l}24-29 \text { Dec, } \\
2012\end{array}$ & \\
\hline 3 & & \begin{tabular}{|l|} 
Bidya Devi \\
Bhandari
\end{tabular} & Nepal & \begin{tabular}{|l} 
17-21 April, \\
2017
\end{tabular} & \\
\hline 4 & & Pranab Mukherjee & India & $\begin{array}{l}2-4 \text { Nov, } \\
2016\end{array}$ & \\
\hline 5 & \begin{tabular}{|l} 
Prime \\
Minister
\end{tabular} & K.P. Sharma Oli & Nepal & $\begin{array}{l}\text { 19-24 Feb. } \\
2016\end{array}$ & \\
\hline 6 & & K.P. Sharma Oli & Nepal & $\begin{array}{l}\text { 6-8 April, } \\
2016\end{array}$ & \\
\hline 7 & & K.P. Sharma & Nepal & $\begin{array}{l}\text { 30-31 May, } \\
2019\end{array}$ & \\
\hline 8 & & Puspakamal Dahal & Nepal & $\begin{array}{l}\text { 15-16 Sep. } \\
2016\end{array}$ & \\
\hline 9 & & Narendra Modi & India & \begin{tabular}{|l}
$3-4$ Aug. \\
2014
\end{tabular} & \\
\hline 10 & & Narendra Modi & India & 9 May, 2018 & \\
\hline
\end{tabular}

However, this does not last for long. Next year, when Nepal announced a date for the promulgation of new constitution, India was not happy with that. India wanted the constitution 
promulgation date to be postponed and its vested interest to be addressed in the constitution. Constitution making is an internal affair of a nation and a country should not be guided by the advice of a foreign country. So, being a sovereign nation, Nepal promulgated its constitution in its own will, without considering the will of India.

India was not happy by this move. So, India imposed blockade on Nepal. This marked the worst time in Nepal India relation. Later efforts were made to normalize the Nepal India relation. And for some time, again, the Nepal India relation was good. But when Kalapani was included in the map of India and Indian Defense Minister inaugurated the road to Mansarobar via Kalapani, then Nepal India relation was cold again. The Sugauli Treaty of 1816 and other evidences clearly show that LimpiyadhuraLipulekh-Kalapani belongs to Nepal. It is a blunder mistake committed by the Indian government and India always wants to put Nepal in its shadow (Shrestha, Nepal India Relation, 2015), which is never acceptable for Nepal. So, Nepal issued a new map of Nepal that includes Limpiyadhura-Lipulekh-Kalapani as Nepal's territory. India is unwilling to accept it. However, being a neighbor country, the only choice left for Nepal is to solve all issues that prevails between Nepal and India need to be resolved through diplomatic channels and dialogues. There is an anti-Indian sentiment growing in Nepal which is not good for both nations.

Time and again, there have been frequent ups and downs in Nepal India relation after 12 points understanding. Now the present government of Nepal wants to have a dialogue with the Indian government but the Indian government is not showing a readiness for a dialogue on this burning issue. Nepal and India have various issues and problems. Nepal is in a position to 
review all the old treaties and agreements of the past and would like to replace them by new treaties and agreements. In the past, all treaties and agreements were in favour of India. Basically, the Peace and Friendship Treaty of 1950 is not in favour of Nepal. It is an unequal treaty. It provides more privilege to India and nothing to Nepal. It is a root cause for conflict between Nepal and India.

As close neighbors, India and Nepal share a unique relationship of friendship and cooperation characterized by open borders and deep-rooted people-to-people contacts of kinship and culture. There has been a long tradition of free movement of people across the borders (Shrestha, 2015). Nepal and Indian Prime Minister were ready for the review of all treaties and agreements between the two countries and made the EPG on 4 August, 2014 - when Indian PM Narendra Modi visited Nepal for the first time. It was announced in the joint statement of both governments. Four members in the EPG from Nepal side include Bhesh Bahadur Thapa (Nepal Co-ordinator), Nilamber Acharya, Suryanath Upadhyaya and Rajan Bhattarai. Similarly, Indian side includes Bhagat Singh Koshyari (Indian Co-ordinator), BC Upreti, Jayant Prasad and Mahendra Prasad Lama in the EPG (Ministry of External Affairs, 2014). EPG held its first meeting on 4 June, 2016 in Nepal. The final ninth meeting of EPG was held on 30 June 2018 in Kathmandu. It has studied and reviewed all the treaties and agreements between Nepal and India thoroughly and prepared the final report. EPG has submitted the report to the government of Nepal. The Nepal government readily accepted the report. However, the government of India has not received the report yet. Indian PM Narendra Modi has not provided a time to look into it. 


\section{Conclusion}

Nepal India relations are historical, social, ethical and cultural embodied since the primitive era. In the modern time, India and Nepal initiated their relationship with the 1950 IndoNepal Treaty of Peace and Friendship that defined security relations between the two countries, and an agreement governing both bilateral trade and trade transiting Indian territory that flagged a special relationship between India and Nepal. In the contemporary period, Nepal India relations need to be cordial and friendly as we are the neighboring countries and we share common culture and civilization as well. Notwithstanding the handy linguistic, marital, religious and cultural ties at peopleto-people level between Indians and Nepalese, since the last few years political issues and border rows have strained relations between the two countries with anti-Indian sentiment growing amongst the government and people of Nepal. Because of border disputes between the two countries, a boundary settlement hasn't yet been approved by either government.

Nepal and India are two independent and sovereign nations and are equal. But India wants to have its influence on Nepal which is not acceptable for Nepal. India is the biggest and powerful nation in South Asia. Its position is vital in South Asia. After 12 points understanding, Nepal India relation has been too tumultuous. Exchange of high-level visits from both sides, constitution making process of Nepal and India's interest on it, blockade, EPG and recently Limpiyadhura-Lipulekh-Kalapani issue have been major events in the Nepal India relation. And, one thing that both countries should agree is that problems should be addressed through proper diplomatic channels and both Nepal and India should respect each other's sovereignty and India being a big nation, it should have a big heart to resolve all unsettled issues between Nepal and India. The steadfast 
obligation to the principles of peaceful coexistence, sovereign equality, and understanding of each other's aspirations and sensitivities need to be the firm foundation on which bilateral relations can grow further. Nepal and India have no choice other than to have a decent relation between the two.

\section{References}

Dahal, G. (2015). Constitutional Assembly of Nepal Milestone for Peace, Development and Political Stability. KMC Journal of Interdisciplinary Studies, 4(1), 70-77.

Dahal, G. (2019). An Overview of Foreign Relation of Nepal with China. Journal of Political Science, 19, 85-99. https:// doi.org/10.3126/jps.v19i0.26700.

Embassy of India in Kathmandu (2019). https://www. indembkathmandu.gov.in/page/contact-us/

Embassy of India in Kathmandu. (2014). Joint Press Statement on the Visit of the Prime Minister to Nepal.

Embassy of India Kathmandu (2015). https://www. indembkathmandu.gov.in/page/amb-profile/

Guruswamy, M. (n.d.) Making of the Constitution in Nepal. https://www.thehindu.com/static/theme/default/base/img/ logo.png

Jha, H. B. (2015). Nepal's Madhesh Movement (Fall 2015). Retrieved from https://allianceforpeacebuilding.org/2015/11/ nepals-madhesh-movement/.

Ministry of External Affairs (2014, August). Joint Press Statement on the Visit of the Prime Minister to Nepal. Retrieved from https://www.mea.gov.in/bilateral documents. htm?dt1/23807/Joint_Press_Statement_on_the_Visit_of_ the_Prime_Minister_to_Nepal.

Ministry of Foreign Affairs Nepal (2019). https://mofa.gov.np/ Shrestha, H. P. (2015). Nepal India Relation. ASIAN, 20-25.

Shrestha, H. P. (n.d.). Can Nepal become Tourist Hub, despite India's air- blockade. http://southasiajournal.net/can-nepalbecome-tourist-hub-despite-indias-air-blockade/

- 75 - Journal of Political Science, Volume XX 